\title{
PUbliC CAPITAL, REgIONAL PRODUCTIVITY AND SPATIAL SPILLOVERS
}

\author{
Carlos Gil Canaleta, Pedro Pascual Arzoz, Manuel Rapún Gárate \\ Department of Economics \\ Public University of Navarra
}

\begin{abstract}
This paper examines the impact of infrastructure on productivity in the various regions of Spain. Using the duality approach and panel data, we estimate the regional cost functions for the three main sectors of the economy for the period 1964-1991. We also estimate a production function with profit maximization restrictions and a production function with regional and temporal fixed effects. Public capital is included as an unpaid factor of production, and two separate variables are used to establish whether the different categories of public capital have varying effects on costs. Results show that public infrastructure noticeably reduces private costs and increases overall productivity.

Finally, there is a study of the existence of spillover effects in transport infrastructure. Estimations suggest that such effects are of some relevance, a fact which may have serious implications for public policy on infrastructure.
\end{abstract}

Key words: regional infrastructures, duality theory, productivity, externalities.

\section{Contacting address:}

Carlos Gil. Departamento de Economía. UPNA. Campus de Arrosadía s/nº. Tel: 948169346. Fax: 948-169721. e-mail: cargil@upna.es 


\section{Introduction}

Over the past decade various investigations have been made into the impact of public capital on economic development. However, the possibility that the stock of public capital could be among the significant variables in the private sector production function is something which had already been considered by ARROW and KURZ, 1970, and GROSSMAN and LUCAS, 1974, being later contrasted by MERA, 1973, for the Japanese regions and RATNER, 1983, for the USA. The key argument to support the inclusion of public capital in the production function is that it increases the productivity of private factors, and that both sources of capital are complementary, so that an increase in public investment brings about an increase in the marginal product of private capital thereby providing an inducement to private investment.

Among other factors which have motivated renewed interest in public capital among economists, we could mention the following. Firstly, studies by ASCHAUER, 1989, and MUNNELL, 1990a,b, estimate production functions in which the elasticity of the product with respect to public capital is surprisingly high. The notion that the decreasing growth rate in the productivity of private factors, apparent since the early seventies, could, in part, be due to a reduction in public investment seemed to hold some truth.

In addition, concern for regional development, which grew with the formation of the European Union, and increasing integration within the Union, have given rise to a great number of studies which analyse the stock of public capital and its influence on the level of national or regional development. One study which had widespread impact at the European level was that carried out by BIEHL et al , 1986.

However, a great number of subsequent studies have, since then, cast doubt on what is known as the "Aschauer effect", at least as far as the estimated degree of elasticity is concerned. The possible effect on these early findings of such econometric problems as reverse causality, the possible omission of variables correlated with public investment or the presence of tendencies in the series estimated, have inspired researchers to concentrate on estimation by panel data, for entire countries as well as for regions. Findings by 
HOLTZ-EAKIN, 1994, EVANS and KARRAS, 1994a,b, GARCÍA-MILÁ, McGUIRE and PORTER, 1993, show how, when regional or time specific variables are controlled using estimations with fixed or random effects, the estimated elasticities are considerably smaller and in some cases completely cancelled out ${ }^{1}$.

Furthermore, alternative methods have been used in an attempt to circumvent these problems. The duality theory provides a means of approaching the problem of producer optimization and identifies the channels through which the effects of public capital are transmitted. This theory enables us to specify cost functions or, their equivalent, profit functions. By minimizing costs or maximizing profits, we are able to obtain the optimum demand for variable and fixed inputs, one of which is the stock of public capital in infrastructure.

The basic theory for this line of research was developed by Diewert 1986, and pioneered by DENO, 1988, using a profit function. BERNDT and HANSSON, 1992, subsequently took the results obtained from the estimation of production functions of the type used by ASCHAUER 1989 and MUNNELL, 1990a, and compared them with those obtained using a cost function for Sweden, their conclusion being that cost function models yield more plausible results. The results obtained by LYNDE and RICHMOND, 1993, for the manufacturing sector in the United Kingdom, also suggest that infrastructure has a positive effect on both costs and production. More recent studies, such as those of NADIRI and MAMUNEAS, 1994, for the USA and SEITZ, 1993a,b, for Germany, estimate national cost functions for various sectors. Studies carried out at regional level are fewer in number, though, as SEITZ and LICHT, 1994, point out, since most types of infrastructure have a clear spatial dimension, regional or even urban disaggregation may be more advisable for this type of study, in spite of possible spillover effects.These same authors have estimated a regional cost function for Germany, as have MORRISON and SCHWARTZ, 1996 for the USA. On the whole, the results obtained show that public capital has a significant positive effect in reducing production costs. 
The cost (profit) function approach offers several advantages over that of the production function. In the first place, it incorporates business behaviour theory by beginning with the hypothesis that businesses minimize (maximize) their production costs (profits) by estimating input demand along with the cost equation. This alternative approach provides the opportunity to study the possible effects of public investment on cost saving and on private input demand at a given level of production. It furthermore offers a means of avoiding some of the econometric problems involved in production functions $^{2}$. This second approach, never previously applied at Spanish regional level, is the one we have chosen to use in this paper.

Our aim is to provide an approximate estimation of the impact of various types of infrastructure on Spanish regional production costs in the agricultural, industrial and services sectors for the period 1964-1991. Regional level analysis may be advisable because many of the infrastructure stocks have close territorial links. In addition, the use of regional data provides a richer sample and the means to make comparisons in order to tell whether the differences in development from one region of Spain to another can be linked to public capital disparities.

The content of this paper is presented as follows. The following section describes the theoretical framework. Section three presents the data used. This is followed by an analysis of the results obtained, after which there is a discussion of the possible existence of spillover effects. Finally, the most significant conclusions of the study are outlined.

\section{A Theoretical Framework}

The main feature of any type of infrastructure is the fact that it is public; that is, it is provided by the State free of charge or at a low price to the user. If infrastructure affects the productivity of private factors of production, at a a given level, a greater stock of infrastructure brings about an increase in production with no cost increase, with the result that the cost per unit of the product is reduced. In this paper, following the practice of most other studies, we will avoid considering that services provided by infrastructure are paid for through taxation ${ }^{3}$. 


\subsection{Cost function model}

If public capital influences the productivity of private factors, it must be included in the cost function:

$$
C=C(Y, w, I, t)
$$

where $C$ is the twice continuously differentiable cost function; $Y$, the production value; $w$, the vector of private input prices; and $I$, the stock of public capital. The time index $t$ is included to allow for technical progress. For ease of notation, this and the following equations do not carry the subindices for sector, region and time.

Costs may be calculated from the amounts and prices of the private factors used:

$$
C=C I^{*} p_{C I}+L^{*} p_{L}+K^{*} p_{K} s
$$

where $C I$ denotes intermediate inputs; $L$, the labour factor; $K$, private capital; and $p_{C}, p_{L}$, $y p_{K}$ the respective prices of these.

In our case, lack of data as to the amount and prices of raw materials or intermediate inputs at regional level obliges us to use the following function:

$$
C=L^{*} p_{L}+K^{*} p_{K}
$$

Our cost function in reality, therefore, is a primary cost function which depends not on the production value but rather on the value added: $Y=V A$. This is how it was expressed by SEITZ y LICHT, $1995^{4}$.

The anticipated effect of infrastructure on the production function implies that $\left(\partial Y_{i} /\right.$ $d I) \geq 0$. This effect can also be evaluated in the cost function, by differentiating [1] with respect to $I$ :

$$
\sigma_{I}=-\frac{\partial C\left(Y, p_{L}, p_{K}, I, t\right)}{\partial I}
$$

where $\sigma_{I}$ denotes the amount by which costs are reduced when public capital is increased by one unit, this is also known as "the shadow price of public capital". Application of the 
envelope theorem (see, for example, CHAMBER, 1988) provides the relationship between the marginal product and the shadow price:

$$
\frac{\partial Y}{\partial I}=\frac{\sigma_{I}}{\frac{\partial C\left(T, p_{L}, p_{K}, I, t\right)}{\partial Y}}
$$

It is to be expected, therefore, that, if the shadow price of the capital is positive, firms located in regions with better infrastructure should have a cost advantage as compared to those located in less well-endowed regions. The implication of this is that the variable $I$ could be used as a strategic weapon in regional politics.

Application of Shephard's Lemma (CHAMBERS, 1988) to the cost equation [1] yields the private factor demand equations. These equations depend upon the supposition that firms demand a combination of capital and labour factors which will minimize their costs for each level of prices and public capital stock:

$$
L^{*}=\frac{\partial C}{\partial p_{L}}, K^{*}=\frac{\partial C}{\partial p_{K}}
$$

The demand functions, therefore, depend on the same variables as the cost function. Available technology, the output level, public capital and factor prices determine the demand for each private factor. Public capital can affect cost structure in the various sectors in two ways. Firstly, more or better infrastructure can reduce the unit cost of a product. In addition, firms will adjust their demand for private factors according to whether public capital is complementary to or substitutive of private factors. When the private factor demand functions are derived with respect to the different types of public capital, the nature of this relationship is revealed:

$$
\varepsilon_{L, I}=\frac{\partial L^{*}}{\partial I}=\frac{\partial^{2} C\left(Y, p_{L}, p_{K}, I, t\right)}{\partial P L \partial I}, \varepsilon_{K, I}=\frac{\partial K^{*}}{\partial I}=\frac{\partial^{2} C\left(Y, p_{L}, p_{K}, I, t\right)}{\partial P K \partial I}
$$

Multiplication by the quotients $I / L$ and $I / K$ respectively yields the corresponding elasticities: 


$$
\eta_{L, I}=\frac{\partial L^{*}}{\partial I} * \frac{I}{L}=e_{L, I} \frac{I}{L}, \eta_{K, I}=\frac{\partial K^{*}}{\partial I} * \frac{I}{K}=e_{K, I} \frac{I}{K}
$$

\subsection{Production function with profit maximization restrictions}

A profit function can be expressed as:

$$
B=f(L, K, I, t)^{*} p_{7}-C=f(L, K, I, t) * p_{y}-\left(L^{*} p_{L}+K^{*} p_{K}\right)
$$

and the maximization conditions are:

$$
\frac{\partial B}{\partial L}=0 \Rightarrow \frac{\partial f(L, K, I, t)}{\partial L}=\frac{p_{L}}{p_{y}}, \frac{\partial B}{\partial K}=0 \Rightarrow \frac{\partial f(L, K, I, t)}{\partial K}=\frac{p_{K}}{p_{y}}
$$

thus, the labour and private capital cost shares in total production must be equal to their elasticities. We can estimate a production function with these constraints.

\subsection{The empirical model}

In order to limit the influence of restrictions, normally imposed a priori, we propose the use of a flexible function, as in most cost-function studies. SinceWe expect relevant differences in the sectorial cost function parameters, we will include sectorial dummy variables for all the exogenous variables. We will also test the significance of regional specific effects, such as locational advantages, including regional dummy variables. These fixed effects should also help us to avoid autocorrelation problems.

Since the cost function needs to be grade 1 homogeneous (that is to say that an increase of the same proportion in private factor prices brings about an equal increase in the total cost) we impose this restriction which requires normalization of input prices by dividing them by the capital price, thereby obtaining the following function: 


$$
\begin{aligned}
& \ln \left(\frac{C}{p_{K}}\right)=a+\sum_{i=2}^{3} a_{i} D_{i}+b_{Y} \ln (Y)+\sum_{i=2}^{3} D_{i} b_{Y, i} \ln (Y)+b_{L} \ln \left(\frac{p_{L}}{p_{K}}\right)+\sum_{i=2}^{3} D_{i} b_{L, i} \ln \left(\frac{p_{L}}{p_{K}}\right)+b_{I} \ln (I)+ \\
& \sum_{i=2}^{3} D_{i} b_{I, i} \ln (I)+b_{t} t+\sum_{i=2}^{3} D_{i} b_{t, i} t+c_{Y, L} \ln (Y) \ln \left(\frac{p_{L}}{p_{K}}\right)+\sum_{i=2}^{3} D_{i} c_{Y, L, i} \ln (Y) \ln \left(\frac{p_{L}}{p_{K}}\right)+c_{Y, I} \ln (Y) \ln (I)+ \\
& \sum_{i=2}^{3} D_{i} c_{Y, I, i} \ln (Y) \ln (I)+c_{Y, t} \ln (Y) t+\sum_{i=2}^{3} D_{i} c_{Y, t, i} \ln (Y) t+c_{L, I} \ln \left(\frac{p_{L}}{p_{K}}\right) \ln (I)+\sum_{i=2}^{3} D_{i} c_{L, I, i} \ln \left(\frac{p_{L}}{p_{K}}\right) \ln (I)+ \\
& c_{L, t} \ln \left(\frac{p_{L}}{p_{K}}\right) t+\sum_{i=2}^{3} D_{i} c_{L, t, i} \ln \left(\frac{p_{L}}{p_{K}}\right) t+c_{I, t} \ln (I) t+\sum_{i=2}^{3} D_{i} c_{I, t, i} \ln (I) t+\sum_{j=2}^{l 7} D R_{j}
\end{aligned}
$$

Application of Shephard's Lemma to this equation yields the function for the labour cost share $\left(S_{L}\right)$ in the total costs:

$$
\begin{aligned}
& S_{L}=\frac{p_{L} * L^{*}}{C}=b_{L}+\sum_{i=2}^{3} D_{i} b_{L, i}+c_{Y, L} \ln (Y)+\sum_{i=2}^{3} D_{i} c_{Y, L, i} \ln (Y)+c_{L, I} \ln (I)+ \\
& \sum_{i=2}^{3} D_{i} c_{L, I, i} \ln (I)+c_{L, t} t+\sum_{i=2}^{3} D_{i} c_{L, t, i} t
\end{aligned}
$$

Since the sum of the cost shares totals 1 , the capital cost share equation cannot be taken into account during the estimation process.

The restricted production function is

$$
\begin{aligned}
& \ln (Y)=a+\sum_{i=2}^{3} a_{i} D_{i}+b_{K} \ln (K)+\sum_{i=2}^{3} D_{i} b_{K, i} \ln (K)+b_{L} \ln (L)+\sum_{i=2}^{3} D_{i} b_{L, i} \ln (L)+b_{I} \ln (I)+ \\
& \sum_{i=2}^{3} D_{i} b_{I, i} \ln (I)+b_{t} t+\sum_{i=2}^{3} D_{i} b_{t, i} t+c_{K, L} \ln (K) \ln (L)+\sum_{i=2}^{3} D_{i} c_{K, L, i} \ln (K) \ln (L)+c_{K, I} \ln (K) \ln (I)+ \\
& \sum_{i=2}^{3} D_{i} c_{K, I, i} \ln (K) \ln (I)+c_{K, t} \ln (K) t+\sum_{i=2}^{3} D_{i} c_{K, t, i} \ln (K) t+c_{L, I} \ln (L) \ln (I)+\sum_{i=2}^{3} D_{i} c_{L, I, i} \ln (L) \ln (I)+ \\
& c_{L, t} \ln (L) t+\sum_{i=2}^{3} D_{i} c_{L, t, i} \ln (L) t+c_{I, t} \ln (I) t+\sum_{i=2}^{3} D_{i} c_{I, t, i} \ln (I) t+\sum_{j=2}^{17} D R_{j}
\end{aligned}
$$

with

$$
\begin{aligned}
& S_{L}=\frac{p_{L} * L^{*}}{Y}=b_{L}+\sum_{i=2}^{3} D_{i} b_{L, i}+c_{K, L} \ln (K)+\sum_{i=2}^{3} D_{i} c_{K, L, i} \ln (K)+c_{L, I} \ln (I)+ \\
& \sum_{i=2}^{3} D_{i} c_{L, I, i} \ln (I)+c_{L, t} t+\sum_{i=2}^{3} D_{i} c_{L, t, i} t
\end{aligned}
$$




$$
\begin{aligned}
& S_{K}=\frac{p_{K} * K^{*}}{Y}=b_{K}+\sum_{i=2}^{3} D_{i} b_{K, i}+c_{Y, L} \ln (K)+\sum_{i=2}^{3} D_{i} c_{Y, L, i} \ln (Y)+c_{L, I} \ln (I)+ \\
& \sum_{i=2}^{3} D_{i} c_{L, I, i} \ln (I)+c_{L, t} t+\sum_{i=2}^{3} D_{i} c_{L, t, i} t
\end{aligned}
$$

For the non restricted production function we have estimated [12] but, as is normal in empirical studies, the variables including $\mathrm{t}$ have been substituted by fixed temporal effects.

\section{Data}

All data used correspond to the period 1964-1991. Data concerning public and private capital are compiled by the IVIE and published by the BBV Foundation. Data on regional GVA have been taken at two-year intervals from series compiled by the BBV and included in regular issues of the publication "Renta Nacional de España y su distribución provincial" ("The Spanish National Income and its distribution throughout the provinces"). The GVA series have been deflated according to the sectorial deflator calculated by the afore-mentioned body in its Annual Report.

The various investigations into the impact of public capital on production or costs all use different variables to measure public capital. In some cases, what is taken into account is the set of infrastructures which can be said to be relevant to production: transport, communications, water supply and sewage disposal, education and health care. In other instances, the different types of public capital are restricted or separated. In this paper, we have opted to estimate the models with a broad variable "public capital" (PC) including transport, hydraulic, urban, education and health care infrastructure, and with a narrower variable, transport infrastructure (TI). The reason for this distinction is that, although we could expect a stronger effect on cost and production of public capital related to transport (roads, ports, airports), the results are in fact weaker ${ }^{5}$. We think that part of this unexpected result is due to the presence of spillover effects, especially important in network-type capital and among regions.

Employment and wage data have also been taken from "Renta Nacional de España y su distribución provincial". The wage figure has been divided by the number of 
employees to obtain the labour unit cost, although this has been multiplied by the total number of employees in each sector for the cost estimation. Wages have been deflated in accordance with the price index for each sector.

In estimating capital costs we have used the concept of "the user cost of capital" as developed by JORGENSON $1963^{6}$ :

$$
p_{K i}=\frac{I P K}{I P S_{i}}\left(\frac{(r+\delta)}{1+\frac{\Delta I P S_{i}}{I P S_{i}}}\right)
$$

where $I P K$ denotes the capital price index; $I P S_{i}$, the price index for the sector; $r$, the interest rate on electricity shares; and $\delta$, the capital depreciation rate.

The price index used is that calculated by the IVIE to deflate the series of productive private capital. Interest rates have been taken from the Bank of Spain's Annual Report. The interest rate on electricity shares has been chosen because it is the only indicator which can be dated back without interruption to the first year of our series. ${ }^{7}$

The depreciation rate for each sector has been calculated by taking the figure obtained from the series compiled by the IVIE. Where the year $=t$, and private capital investment $=\operatorname{Inv} K$ :

$$
\delta_{t}=\frac{\left(K_{t-1}+\operatorname{Inv} K_{t}\right)-K_{t}}{K_{t}}
$$

A highly detailed cost function would need to include rather than the stock of public capital, the services provided to firms by them. Because of the obvious difficulty involved in measuring such services, the stock is used as a proxy variable. The stock is often adjusted in order to reflect a heavier use of any particular variable. Arguments to the effect that road use by firms changes over the years in proportion to their production level, that the number of school-age children varies, or that congestion in some services can reduce use by the productive sector during some periods, have led to adjustments in these variables by an index, usually the capital utilization rate. 
In this study, we have not adjusted the stock of capital with variables to bring us nearer to the volume of production. This is mainly because there is no suitable variable available, but also for economic reasons. Adjustment can give rise to false correlations, because the close correlation between production and this kind of rate would produce a similar effect between the variable (public capital*utilization rate) and production. In any event, studies comparing estimations with adjusted and unadjusted public capital have found results to be similar ${ }^{8}$.

A second issue is whether to estimate average or total cost functions. Empirical studies of regions use total cost functions, while national studies of sectors tend to opt for estimating average costs. No reason is usually given for preferring one method to the other. In our opinion, total cost functions make it necessary either to calculate the approximate amount of public capital used by each sector or to estimate a cost function for each sector. Average cost functions do not require these adjustments, since the average costs for any sector will benefit equally from an improvement in infrastructure, which would suggest that they are the more suitable for national studies.

In regional studies, the estimation of an average cost function presents a further problem: the difference in size between regions (in Spain quite marked) both with respect to area and population, which can affect results. Larger regions will obviously have received greater public investment, but this not mean that their stock of public capital is better. To illustrate this point, the following table shows the ratios of stock of economic infrastructure to private capital, population and area per region.

We consider that the comparison of data across the different regions is the main difficulty which arises when using panel data to assess the impact of infrastructure on the cost function. The problem becomes even more complex if we take into account the fact that building costs of some infrastructures, particularly roads, differ from one region to another. In this case it is likely that the monetary indicators used are not as suitable as the physical ones. This does not mean, however, that regional analysis is not useful. 
Comparison of how infrastructure stocks evolve throughout the regions provides a wealth of data which would be impossible to obtain from national figures.

\section{Results}

Equations 10 and 11 have been estimated using maximum likelihood estimation of a constrained system allowing for regional specific effects. We hope in this way to be able to obtain a closer estimate of the varying impact that an infrastructure stock of similar monetary value can have in different regions. Equations 12, 13 and 14 have been estimated in the same way. The production function without restrictions has been estimated with temporal and regional fixed effects ${ }^{9}$.

The results of the six estimations (two for each model: the first with public capital and the second with transport infrastructure) are shown in tables 7,8 and 9. Although the variables including public capital are not in all cases significant, the likelihood ratio tests indicate their overall significance (tables $7 \mathrm{~b}, 8 \mathrm{~b}$, and 9b). Region-specific and sectorspecific dummies also prove to be significantly different from zero. We have confirmed that the cost function fulfils regularity conditions: it is increasing for production and concave in price inputs at each point of the sample.

Table 2 shows the average regional cost elasticities with respect to public capital and transport infrastructure in each sector, for the beginning, middle and end of the period.

It can be seen how industry and services show similar cost/public capital elasticities, slightly higher in in the secondary sector and greater than in agriculture. Estimated elasticities for industry are similar to those obtained by other authors ${ }^{10}$. The lower elasticity observed in the agricultural sector could be due to any one of a variety of factors: the influence of weather conditions or changes in agricultural prices, or even unreliable statistics.

For agriculture, the results change substantially from one estimation to another and over time. The influence in agriculture of such uncontrolled variables as soil quality, weather conditions, subsidies or international price fluctuations, as well as the actual reliability of the statistical data (a substantial part of the workforce may be made up of 
black labour ${ }^{11}$ ) means that we must exercise caution in our interpretation. Another aspect also worthy of consideration is the heterogeneous nature of the agricultural sector throughout the regions of Spain, both with respect to production functions and to costs.

Care is also necessary when it comes to evaluating and interpreting our estimations for the services sector, since less competition and the weight of the services provided by the public administration are factors which must be borne in mind.

Paradoxically, those for the model including exclusively transport infrastructures, are the lowest. A possible explanation for this is that in this type of public capital a greater discrepancy can arise between measurements made in monetary terms and those made in physical terms. It must also be borne in mind that this type of capital stock is of a more pronounced public character, in so far as its use is "non-exclusive". A region with a low ratio of transport infrastructure to private capital may actually be much better off than one in the opposite situation. A case in point is that of Madrid which is the least well-endowed if we are to judge by its ratios of economic infrastructure to private capital or to population, in comparison to the two Castiles or Extremadura, regions for which these ratios are much more favourable (table 1).

A further issue which can be addressed from this approach is the effect of a variation in infrastructure stocks on factor demand. This overall effect is comprised of two elements. The first, which could be referred to as the productivity effect, is a result of the reduction in private costs per product unit which comes about as a consequence of the increase in public capital. This effect can be measured with the cost elasticity of infrastructure and is shown in tables 2 and 3. To make cross-checking easier, it has also been included for model 1 in table 4.

The second effect, known as the total cost share, can be measured by using the cost share elasticity values for public capital: $(\partial S i / \partial \ln I) / S i$, when $i=K, L)$. As can be seen from the results in table 4, an increase in infrastructure causes an increase in the private capital cost share over total cost $\left(E l a S_{K} / I\right)$., and hence a relative increase in capital demand Obviously, there is a reduction in the labour cost share $\left(\operatorname{ElaS}_{L} / I\right)$. 
The sum of these effects demonstrates the impact that an increase in infrastructures will have on factor demand (under the hypothesis of fixed output). The net effect on labour is, due to the substitution of inputs, almost 5 points greater than that on private capital.

These conclusions are backed up by the results of the production functions with and without maxmization restrictions. Table 5 shows average production elasticities for the three models.

The elasticities for the production and profits function for the industrial sector are greater than for other sectors, and similar to those obtained for other regions of Spain by MAS et al. We notice a slight fall throughout the period in the three models, and a substantial reduction in elasticities when we use transport infrastructures, negative values being reached in the year 1991. The results of the two new estimations, therefore, confirm those obtained from the cost function.

One of the reasons which would explain the lower cost elasticities with respect to infrastructure in the model which includes $T I$, is that the relevant spatial reference for transport infrastructure is not of a regional nature. Road improvements in one region can have an effect on transport costs in its neighbouring regions, giving rise to "spillover" effects, the extent of which we have not calculated, but of which we will attempt to give an approximate estimation in the next section.

\section{Spatial productivity spillover effects in transport infrastructure}

Our results may be revealing the presence of so-called "spillover effects", that is, the fact that public capital, and specifically transport infrastructure, provides services to producers outside the region in which it is located. What is crucial, therefore, is not the transport infrastructure of the individual region, but rather, that of the country as a whole. The danger that such effects may prevent regional estimations from accurately reflecting the impact of public capital was first suggested by MUNNELL, 1990b, on discovering that the estimated elasticity for individual states in the USA was approximately half that estimated for the country as a whole. 
Few studies concentrate specifically on the analysis of spillover effects. HOLTZEAKIN and SCHWARTZ, 1995, create a production function in which they incorporate a variable to measure the "effective" stock of roads and motorways, which captures varying combinations of this type of infrastructure in the entire US and in the member states. Their findings are unfavourable from the point of view of the spillover hypothesis.

Although it does not constitute the main aim of their study, MAS et al 1994 compare the results of production functions for Spain which include only the region's own stock of public capital, with those obtained by adding to this that of the bordering regions. Elasticities are greater in the second case, leading these researchers to conclude that there is positive evidence to support the spillover effect hypothesis.

It is not easy to confirm the existence of spillover effects in transport infrastructures, and none of the methods used in the studies we have quoted is without its problems. Our own standpoint, however, differs from that taken in these studies. A variable is needed which will represent the stocks which are relevant in each region. The proxy variable which we will use in our attempt to reflect spillover depends upon the hypothesis that the infrastructures most relevant to any region are the ones which belong to those other regions with which it has the strongest commercial ties. In this way we bring the concept of public capital closer to that of "service provided by public capital", which is crucial for cost analysis.

The new variable ${ }^{12}$, which will be named "spillover effect", $S E$, for region i, es:

$$
S E_{i}=\sum_{j=1}^{15} T I_{j} * F T_{j, i}
$$

Where $T I_{j}$ are the transport infrastructures of the region $j$; and $F T_{j, i}$ the share in the total flow of trade towards $j$ taken up by trade from $i$.

$S E_{i}$ is a linear combination of the infrastructure in region $i$, multiplied by the rate of trade flow with origin and destination in the region $i$ on the total flow of trade with 
destination $i$, and of the stock of the remaining communities, also multiplied by the rate of trade from i towards $j$ on the total flow with destination $j$.

Use of these rates enables us to "weight" more heavily those regions with closer ties. Nor does the capital-costs relationship suffer, since the new variable possesses the property whereby $\Sigma S E$ coincides with $\Sigma T I$.

Data relevant to the exchange of goods between regions are taken from the study by ARCARONS et al, 1992. The only data at our disposal are those for the year 1987, and it is these which have been used to create the variable $S E$ for the whole period.

The estimated parameters are in the last two columns of tables 7, 8 and 9. Table 6 shows the results from estimation with our variable $S E$, together with those obtained by using transport infrastructures $(T I)$. Variables $S E$ and $T I$ are highly correlated, since the flow of trade to and from the region $\left(F T_{i, i}\right)$ is in all cases more than $60 \%$ of the total, and in several cases exceeds $80 \%$. In addition, since the flow of trade data is for a single year, time variations are minimal. This means that there was no reason to expect a significant alteration in estimations. However, cost and product elasticities are noticeably higher in the model incorporating $S E$ (around $4 \%$ on average) which suggests the possible presence of spillover effects.

The analysis of spillover effects is only the first outcome of a line of research which we intend to follow up in the future. Other ways of weighting variables will need to be used and incorporated into the production and cost functions in order to confirm or refute the findings of this study.

\section{Conclusion}

Our findings show that public capital reduces private production costs, in this way coinciding with all studies of cost functions for other countries, both at national and regional level.

As far as the results for sectors are concerned, the greatest savings in private costs for each additional unit of public investment occur in the industrial sector, followed by the 
service sector. Cost savings through public investment have a positive effect on production, especially in the two sectors just mentioned. Estimated elasticities are slightly higher than those obtained in recent studies made to estimate regional production functions.

We have also confirmed that public capital and private capital factors are complementary, while labour and public capital are substitutive. The sum of productivity effects and cost shares shows that, in a fixed production context, an increase in infrastructure gives rise to a five points greater decrease in labour than in private capital. This effect is very similar in the three sectors. The increased in private productivity brougth about caused by the infrastructure investment should, at any rate, offset the negative impact on the labour demand.

In consequence, therefore, and with all due caution, these conclusions confirm the idea of the necessity of a public policy on infrastructure.

In addition, we have discovered evidence to support the hypothesis of the spillover effect. The presence of this effect has serious implications for infrastructure policy, in particular in a decentralized framework such as that of Spain. More precisely, with a view to efficiency, the suggestion which arises is of the need for a centralized source of public capital, or for very close coordination and planning between the various Autonomous Communities holdingpower in the region. Likewise, it would seem useful to bear this effect in mind when drawing up the conditions for the transfer of responsability for infrastructures and also in the ongoing debate concerning the exact degree of responsability to be transferred. 


\section{Tables}

Table 1. Economic infrastructure indicators ${ }^{(1)}$

\begin{tabular}{lcccccc}
\hline Region & EI/ private capital & Position & EI/area & Position & EI/ population & Position \\
\hline Andalusia & 0.15 & 7 & 7.88 & 12 & 106 & 15 \\
Aragon & 0.16 & 5 & 5.03 & 15 & 202 & 4 \\
Asturias & 0.15 & 9 & 19.61 & 5 & 188 & 5 \\
Balearic Is. & 0.12 & 12 & 19.52 & 6 & 159 & 8 \\
Canary Is. & 0.21 & 3 & 29.57 & 3 & 161 & 7 \\
Cantabria & 0.09 & 16 & 14.04 & 10 & 147 & 9 \\
Castile Mancha & 0.16 & 6 & 3.08 & 16 & 145 & 10 \\
Castile Leon & 0.17 & 4 & 5.18 & 14 & 187 & 6 \\
Catalonia & 0.10 & 14 & 22.92 & 4 & 128 & 11 \\
Extremadura & 0.14 & 10 & 3.00 & 17 & 113 & 13 \\
Galicia & 0.15 & 8 & 11.97 & 11 & 128 & 12 \\
The Rioja & 0.26 & 1 & 16.76 & 8 & 332 & 1 \\
Madrid & 0.08 & 17 & 40.30 & 2 & 73 & 17 \\
Murcia & 0.10 & 15 & 6.67 & 13 & 80 & 16 \\
Navarre & 0.24 & 2 & 14.46 & 9 & 302 & 2 \\
Basque Country & 0.13 & 11 & 57.85 & 1 & 204 & 3 \\
Valencia & 0.12 & 13 & 16.93 & 7 & 111 & 14 \\
\hline
\end{tabular}

(1) Averages for 1964-1991

Source: Authors' own estimates using IVIE data.

Table 2. Public capital cost elasticities ${ }^{(1)}$

\begin{tabular}{|c|c|c|c|c|c|c|}
\hline & 1964 & & 1991 & & Media & \\
\hline & PC & TI & PC & TI & PC & TI \\
\hline Agriculture & -0.052 & 0.088 & -0.232 & 0.026 & -0.144 & 0.053 \\
\hline Industry & -0.219 & -0.081 & -0.113 & 0.014 & -0.154 & -0.024 \\
\hline Services & -0.206 & -0.086 & -0.099 & 0.056 & -0.145 & -0.011 \\
\hline
\end{tabular}

(1) Regional averages by sectors for the years 1964 y 1991. and average for the period

Table 3. Cost elasticity of public capital for each region and sector ${ }^{(1)}$

\begin{tabular}{|l|c|c|c|c|c|c|}
\hline & \multicolumn{2}{|c|}{ Agriculture } & \multicolumn{2}{c|}{ Industry } & \multicolumn{2}{c|}{ Services } \\
\hline Region & PC & TI & PC & TI & PC & TI \\
\hline Andalusia & -0.052 & 0.158 & -0.059 & 0.043 & -0.069 & 0.031 \\
\hline Aragon & -0.136 & 0.061 & -0.159 & -0.027 & -0.158 & -0.018 \\
\hline Asturias & -0.175 & 0.02 & -0.152 & -0.02 & -0.174 & -0.027 \\
\hline Balearic Is. & -0.207 & -0.02 & -0.249 & -0.093 & -0.16 & -0.019 \\
\hline Canary Is. & -0.158 & 0.036 & -0.211 & -0.065 & -0.145 & -0.011 \\
\hline Cantabria & -0.197 & -0.006 & -0.237 & -0.082 & -0.214 & -0.05 \\
\hline La Mancha & -0.102 & 0.099 & -0.165 & -0.033 & -0.164 & -0.021 \\
\hline Castile-Leon & -0.083 & 0.122 & -0.111 & 0.007 & -0.121 & 0.003 \\
\hline Catalonia & -0.104 & 0.101 & 0.019 & 0.1 & -0.042 & 0.046 \\
\hline Extremadura & -0.138 & 0.056 & -0.249 & -0.094 & -0.194 & -0.038 \\
\hline Galicia & -0.09 & 0.12 & -0.123 & -0.003 & -0.125 & $5 \mathrm{E}-04$ \\
\hline The Rioja & -0.198 & -0.01 & -0.307 & -0.135 & -0.26 & -0.076 \\
\hline Madrid & -0.209 & -0.027 & -0.043 & 0.056 & -0.038 & 0.047 \\
\hline Murcia & -0.159 & 0.034 & -0.211 & -0.066 & -0.187 & -0.034 \\
\hline Navarre & -0.181 & 0.009 & -0.224 & -0.074 & -0.215 & -0.05 \\
\hline Basque Country & -0.161 & 0.04 & -0.069 & 0.039 & -0.118 & 0.003 \\
\hline Valencia & -0.099 & 0.105 & -0.061 & 0.041 & -0.088 & 0.021 \\
\hline Average & -0.144 & 0.053 & -0.154 & -0.024 & -0.145 & -0.011 \\
\hline
\end{tabular}

(1) average values for the period 
Table 4. Elasticities of labour cost and private capital shares with respect to public capital. and product elasticity with respect to public capital ${ }^{(1)}$

\begin{tabular}{|c|c|c|c|c|c|c|c|c|c|}
\hline & \multicolumn{3}{|c|}{$\operatorname{ElaS}_{L} / I$} & \multicolumn{3}{|c|}{$\operatorname{ElaS}_{K} / I$} & \multicolumn{3}{|c|}{ ElaC/I } \\
\hline & 1964 & 1991 & Av'ge & 1964 & 1991 & Av'ge & 1964 & 1991 & Av'ge \\
\hline Agricul. & -0.012 & -0.018 & -0.015 & 0.123 & 0.029 & 0.055 & -0.052 & -0.232 & -0.144 \\
\hline Industry & -0.015 & -0.015 & -0.015 & 0.038 & 0.035 & 0.035 & -0.219 & -0.113 & -0.154 \\
\hline \multirow[t]{3}{*}{ Services } & -0.013 & -0.013 & -0.013 & 0.065 & 0.05 & 0.055 & -0.206 & -0.099 & -0.145 \\
\hline & \multicolumn{3}{|c|}{ Total effect $L$} & \multicolumn{3}{|c|}{ Total effectK } & & & \\
\hline & 1964 & 1991 & Av'ge & 1964 & 1991 & Av'ge & & & \\
\hline Agricul. & -0.064 & -0.25 & -0.159 & 0.071 & -0.203 & -0.089 & & & \\
\hline Industry & -0.234 & -0.128 & -0.169 & -0.18 & -0.078 & -0.119 & & & \\
\hline Services & -0.219 & -0.086 & -0.153 & -0.141 & -0.049 & -0.09 & & & \\
\hline
\end{tabular}

(1) Values calculated for model 1 (I = total public capital) in $\%$

Ela $_{L} / I=$ Labour share effect: $\partial \ln S_{L} / \partial \ln I$

ElaS $_{K} / I=$ Private capital share effect: $\partial \ln S_{K} / \partial \ln I$

ElaC/I = Cost effect: $\partial \ln C / \partial \ln I$

Table 5. A comparison of production elasticities when estimating with $T I$ or $S E$

\begin{tabular}{|l|rrr|rrr|rrr|}
\hline & \multicolumn{3}{|c|}{ Cost function } & \multicolumn{2}{c|}{ Restricted Production f. } & \multicolumn{3}{c|}{ Production function } \\
\hline Sector & 1964 & 1991 & Av'ge & 1964 & 1991 & Av'ge & 1964 & 1991 & Av'ge \\
\hline \multicolumn{8}{|c|}{ Transport infrastructure. TI } \\
\hline Agriculture & -0.095 & -0.028 & -0.058 & 0.062 & -0.068 & 0.002 & -0.045 & 0.117 & 0.054 \\
\hline Industry & 0.088 & -0.012 & 0.028 & 0.181 & -0.033 & 0.079 & 0.168 & 0.122 & 0.138 \\
\hline Services & 0.087 & -0.058 & 0.012 & 0.13 & -0.06 & 0.035 & 0.096 & -0.013 & 0.031 \\
\hline \multicolumn{10}{|c|}{ Spillover Effect. SE } \\
\hline Agriculture & -0.066 & 0.02 & -0.017 & 0.081 & -0.043 & 0.022 & 0 & 0.137 & 0.088 \\
\hline Industry & 0.137 & 0.04 & 0.073 & 0.223 & 0.004 & 0.118 & 0.216 & 0.155 & 0.177 \\
\hline Services & 0.143 & -0.024 & 0.055 & 0.177 & -0.045 & 0.066 & 0.093 & -0.013 & 0.028 \\
\hline
\end{tabular}

Table 6. Production Elasticities (regional average). ElaY/I.

\begin{tabular}{|l|rrr|rrr|rrr|}
\hline & \multicolumn{3}{|c|}{ Cost function } & \multicolumn{2}{c|}{ Restricted Production f. } & \multicolumn{3}{c|}{ Production function } \\
\hline Sector & 1964 & 1991 & Av'ge & 1964 & 1991 & Av'ge & 1964 & 1991 & Av'ge \\
\hline \multicolumn{10}{|c|}{ Public capital: PC } \\
\hline Agriculture & 0.061 & 0.268 & 0.165 & 0.077 & -0.031 & 0.025 & 0.239 & 0.312 & 0.296 \\
\hline Industry & 0.247 & 0.131 & 0.173 & 0.214 & 0.068 & 0.146 & 0.233 & 0.178 & 0.198 \\
\hline Services & 0.218 & 0.11 & 0.156 & 0.196 & 0.043 & 0.12 & 0.065 & -0.018 & 0.014 \\
\hline \multicolumn{8}{|c|}{ Transport Infrastructure: TI } \\
\hline Agriculture & -0.095 & -0.028 & -0.058 & 0.062 & -0.068 & 0.002 & -0.045 & 0.117 & 0.054 \\
\hline Industry & 0.088 & -0.012 & 0.028 & 0.181 & -0.033 & 0.079 & 0.168 & 0.122 & 0.138 \\
\hline Services & 0.087 & -0.058 & 0.012 & 0.13 & -0.06 & 0.035 & 0.096 & -0.013 & 0.031 \\
\hline
\end{tabular}


Table 7.a. Parameter estimates for the cost function

\begin{tabular}{|c|c|c|c|c|c|c|}
\hline Parameter & \multicolumn{2}{|c|}{$\mathrm{I}=\mathrm{PC}$} & \multicolumn{2}{|c|}{$\mathrm{I}=\mathrm{TI}$} & \multicolumn{2}{|c|}{$\mathrm{I}=$ Spillover Effect } \\
\hline & Estimate & $\mathrm{t}$ & Estimate & $\mathrm{t}$ & Estimate & $\mathrm{t}$ \\
\hline Cte & 10.33 & 3.51 & 9.313 & 3.45 & 11.36 & 3.96 \\
\hline DI & 7.747 & 2.61 & 2.34 & 0.81 & 4.182 & 1.35 \\
\hline $\mathrm{DS}$ & 2.258 & 0.76 & -3.35 & -1.15 & -2.35 & -0.75 \\
\hline$Y$ & 0.233 & 0.84 & 0.189 & 0.73 & 0.048 & 0.18 \\
\hline $\mathrm{Y} 2$ & -0.47 & -1.71 & -0.03 & -0.11 & -0.17 & -0.57 \\
\hline Y3 & -0.02 & -0.09 & 0.397 & 1.47 & 0.359 & 1.25 \\
\hline $1\left(\mathrm{P}_{\mathrm{L}} / \mathrm{P}_{\mathrm{K}}\right)$ & 0.886 & 12.1 & 0.848 & 11.8 & 0.792 & 10.5 \\
\hline $1\left(\mathrm{P}_{\mathrm{L}} / \mathrm{P}_{\mathrm{K}}\right) 2$ & -0.3 & -2.91 & -0.3 & -3.02 & -0.26 & -2.46 \\
\hline $1\left(P_{L} / P_{K}\right) 3$ & -0.21 & -2.02 & -0.14 & -1.41 & -0.1 & -0.93 \\
\hline $\mathrm{I}$ & -0.64 & -2.73 & -0.63 & -2.74 & -0.8 & -3.29 \\
\hline $\mathrm{I} 2$ & -0.69 & -2.85 & -0.25 & -1.04 & -0.42 & -1.56 \\
\hline $\mathrm{I} 3$ & -0.39 & -1.61 & 0.09 & 0.36 & -0.02 & -0.06 \\
\hline $\mathrm{t}$ & 0.282 & 5.7 & 0.206 & 4.23 & 0.239 & 4.85 \\
\hline $\mathrm{t} 2$ & -0.14 & -2.23 & -0.18 & -2.79 & -0.16 & -2.34 \\
\hline $\mathrm{t} 3$ & -0.15 & -2.39 & -0.2 & -3.09 & -0.19 & -2.88 \\
\hline $\mathrm{Yl}\left(\mathrm{P}_{\mathrm{I}} / \mathrm{P}_{\mathrm{K}}\right)$ & 0.005 & 0.58 & -0 & -0.29 & -0.01 & -0.95 \\
\hline $\mathrm{Yl}\left(\mathrm{P}_{\mathrm{I}} / \mathrm{P}_{\mathrm{K}}\right) 2$ & 0.024 & 1.83 & 0.021 & 1.71 & 0.021 & 1.61 \\
\hline $\mathrm{Yl}\left(\mathrm{P}_{\mathrm{I}} / \mathrm{P}_{\mathrm{K}}\right) 3$ & -0 & -0.03 & 0.013 & 1.21 & 0.016 & 1.31 \\
\hline $\mathrm{YI}$ & 0.055 & 2.52 & 0.065 & 2.97 & 0.076 & 3.38 \\
\hline YI2 & 0.04 & 1.85 & 0.003 & 0.13 & 0.015 & 0.63 \\
\hline YI3 & 0.008 & 0.39 & -0.03 & -1.34 & -0.02 & -1.04 \\
\hline $\mathrm{Yt}$ & -0.01 & -1.72 & -0.01 & -2.99 & -0.01 & -3.14 \\
\hline $\mathrm{Yt} 2$ & -0.01 & -0.81 & 0.006 & 0.93 & 0.005 & 0.76 \\
\hline Yt3 & -0 & -0.47 & 0.005 & 0.81 & 0.002 & 0.37 \\
\hline $1\left(\mathrm{P}_{\mathrm{I}} / \mathrm{P}_{\mathrm{K}}\right) \mathrm{I}$ & -0 & -0 & 0.01 & 1.21 & 0.02 & 2.24 \\
\hline $1\left(\mathrm{P}_{\mathrm{L}} / \mathrm{P}_{\mathrm{K}}\right) \mathrm{I} 2$ & -0.02 & -1.25 & -0.02 & -1.07 & -0.02 & -1.14 \\
\hline $1\left(\mathrm{P}_{\mathrm{L}} / \mathrm{P}_{\mathrm{K}}\right) \mathrm{I} 3$ & 0.009 & 0.57 & -0.01 & -0.86 & -0.02 & -1.12 \\
\hline $1\left(\mathrm{P}_{\mathrm{L}} / \mathrm{P}_{\mathrm{K}}\right) \mathrm{t}$ & -0.03 & -20.3 & -0.03 & -22.3 & -0.03 & -22.6 \\
\hline $1\left(\mathrm{P}_{\mathrm{L}} / \mathrm{P}_{\mathrm{K}}\right) \mathrm{t} 2$ & 0.025 & 12.7 & 0.025 & 13.6 & 0.026 & 13.7 \\
\hline $1\left(\mathrm{P}_{\mathrm{L}} / \mathrm{P}_{\mathrm{K}}\right) \mathrm{t} 3$ & 0.023 & 11.7 & 0.025 & 13.2 & 0.025 & 13.3 \\
\hline It & -0.02 & -4.01 & -0.01 & -1.82 & -0.01 & -2.26 \\
\hline It 2 & 0.016 & 2.17 & 0.008 & 1.12 & 0.007 & 0.83 \\
\hline It3 & 0.018 & 2.74 & 0.016 & 2.26 & 0.018 & 2.34 \\
\hline $\mathrm{LL}$ & & 1245.7 & & 1230.8 & & 1236.3 \\
\hline
\end{tabular}

Table 7.b. Hypothesis testing

\begin{tabular}{|l|l|l|c|c|}
\hline & Restrictions & Log likelihood & CHI-2 & D.F. \\
\hline$P C$ & $\mathrm{I}=\mathrm{YI}=\mathrm{LI}=\mathrm{It}=0$ & 1213.5 & 64.4 & 12 \\
\hline & $\mathrm{DR}=0$ & 1070.4 & 350.6 & 16 \\
\hline & $\mathrm{DS}=0$ & 574.6 & 1342.2 & 22 \\
\hline & $\mathrm{I}=\mathrm{YI}=\mathrm{LI}=\mathrm{It}=0$ & 1213.5 & 34.6 & 12 \\
\hline & $\mathrm{DR}=0$ & 1048.1 & 365.4 & 16 \\
\hline$S E$ & $\mathrm{DS}=0$ & 556.9 & 1347.8 & 22 \\
\hline & $\mathrm{I}=\mathrm{YI}=\mathrm{LI}=\mathrm{It}=0$ & 1213.5 & 45.6 & 12 \\
\hline & $\mathrm{DR}=0$ & 1051.8 & 369 & 16 \\
\hline & $\mathrm{DS}=0$ & 569.5 & 1333.6 & 22 \\
\hline
\end{tabular}


Table 8. Parameter estimates for the restricted production function

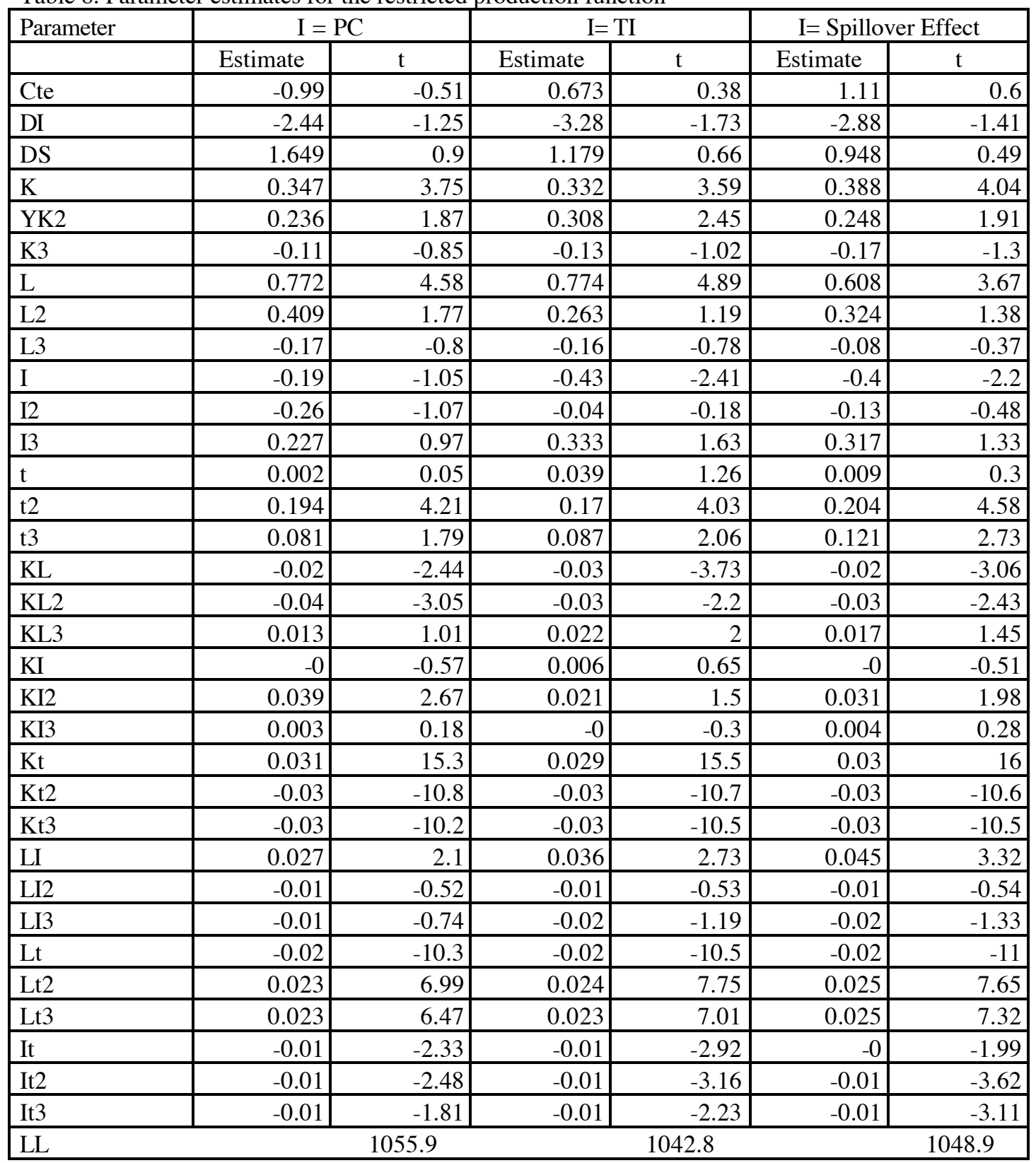

Table 8.b. Hypothesis testing

\begin{tabular}{|l|l|l|c|c|}
\hline & Restrictions & Log likelihood & CHI-2 & D.F. \\
\hline$P C$ & I=YI=LI=It=0 & 985.8 & 140.2 & 12 \\
\hline & DR=0 & 850.7 & 410.4 & 16 \\
\hline & DS=0 & -280.4 & 2672.6 & 22 \\
\hline & $\mathrm{I}=\mathrm{YI}=\mathrm{LI}=\mathrm{It}=0$ & 985.8 & 114 & 12 \\
\hline & $\mathrm{DR}=0$ & 850.4 & 384.8 & 16 \\
\hline & $\mathrm{DS}=0$ & -281.3 & 2648.2 & 22 \\
\hline & $\mathrm{I}=\mathrm{YI}=\mathrm{LI}=\mathrm{It}=0$ & 985.8 & 126.2 & 12 \\
\hline & $\mathrm{DR}=0$ & 857.8 & 382.2 & 16 \\
\hline & $\mathrm{DS}=0$ & -278.5 & 2654.8 & 22 \\
\hline
\end{tabular}


Table 9.a. Parameter estimates for the production function without restrictions

\begin{tabular}{|l|c|c|c|c|c|c|}
\hline Parameter & \multicolumn{2}{|c|}{$\mathrm{I}=\mathrm{PC}$} & \multicolumn{2}{c|}{$\mathrm{I}=\mathrm{TI}$} & \multicolumn{2}{c|}{$\mathrm{I}=$ Spillover Effect } \\
\hline & Estimate & $\mathrm{t}$ & Estimate & $\mathrm{t}$ & Estimate & $\mathrm{t}$ \\
\hline $\mathrm{K}$ & 0.375 & 1.40 & 0.002 & 0.01 & 0.1032 & 0.35 \\
\hline K2 & 0.5834 & 1.16 & 1.1855 & 2.15 & 1.0302 & 1.82 \\
\hline K3 & 1.429 & 1.93 & 2.1434 & 3.04 & 2.1414 & 2.73 \\
\hline L & 1.6548 & 6.05 & 1.8543 & 6.83 & 1.7065 & 5.85 \\
\hline L2 & -1.928 & -4.70 & -1.934 & -4.53 & -2.043 & -4.52 \\
\hline L3 & -2.03 & -3.09 & -2.489 & -3.63 & -2.48 & -3.37 \\
\hline I & -0.998 & -4.70 & -0.725 & -2.99 & -0.815 & -3.44 \\
\hline I2 & 1.2896 & 3.61 & 0.723 & 1.80 & 0.9904 & 2.32 \\
\hline I3 & 0.7159 & 1.83 & 0.444 & 1.32 & 0.436 & 1.14 \\
\hline KL & -0.107 & -6.76 & -0.069 & -3.95 & -0.074 & -4.38 \\
\hline KL2 & 0.1196 & 3.99 & 0.0531 & 1.63 & 0.074 & 2.17 \\
\hline KL3 & 0.0782 & 2.42 & 0.0306 & 1.13 & 0.0335 & 1.11 \\
\hline KI & 0.0922 & 6.00 & 0.1046 & 6.11 & 0.0993 & 5.57 \\
\hline KI2 & -0.144 & -4.85 & -0.15 & -4.56 & -0.157 & -4.53 \\
\hline KI3 & -0.199 & -4.09 & -0.24 & -4.47 & -0.239 & -4.15 \\
\hline LI & 0.0154 & 0.59 & -0.043 & -1.46 & -0.026 & -0.90 \\
\hline LI2 & 0.0346 & 0.78 & 0.1045 & 2.02 & 0.09 & 1.70 \\
\hline LI3 & 0.1236 & 1.97 & 0.2132 & 3.37 & 0.2086 & 2.96 \\
\hline Cte & -1.124 & -0.54 & -1.076 & -0.55 & -0.376 & 0.00 \\
\hline LL & 401.8 & & 374.9 & & 375.2 & \\
\hline
\end{tabular}

Table 9.b. Hypothesis testing

\begin{tabular}{|c|c|c|c|c|}
\hline & Restrictions & Log likelihood & $\mathrm{CHI}-2$ & D.F. \\
\hline \multirow[t]{3}{*}{$P C$} & $\mathrm{I}=\mathrm{YI}=\mathrm{LI}=\mathrm{It}=0$ & 338.1 & 127.4 & 12 \\
\hline & $\mathrm{DR}=0$ & 303.1 & 196.5 & 16 \\
\hline & $\mathrm{DS}=0$ & -457.9 & 1899.4 & 22 \\
\hline \multirow[t]{3}{*}{$T I$} & $\mathrm{I}=\mathrm{YI}=\mathrm{LI}=\mathrm{It}=0$ & 338.1 & 73.6 & 12 \\
\hline & $\mathrm{DR}=0$ & 254 & 41.8 & 16 \\
\hline & $\mathrm{DS}=0$ & -457.7 & 1165.2 & 22 \\
\hline \multirow[t]{3}{*}{$S E$} & $\mathrm{I}=\mathrm{YI}=\mathrm{LI}=\mathrm{It}=0$ & 338.1 & 74.2 & 12 \\
\hline & $\mathrm{DR}=0$ & 261.4 & 227.6 & 16 \\
\hline & $\mathrm{DS}=0$ & -457.9 & 1666.2 & 22 \\
\hline
\end{tabular}




\section{Notes}

${ }^{1}$ GRAMLICH (1994) revises the greater part of the literature concerning the effects of infrastructure. DE LA FUENTE (1996) also revises all these studies, with a brief explanation of the econometric problems affecting early findings.

2 For an analsysis of the advantages and disadvantages of each theoretical approach, please consult BERNDT (1991).

${ }^{3}$ The majority of the afore-mentioned studies consider infrastructure as an unpaid factor. This is not a very realistic supposition, since infrastructure is financed through a variety of taxes, paid licences, tolls, etc. However, infrastructure may be taken to be impure public goods. In this case, taxation on income or production will be preferred because this internalizes excessive or over-use of infrastructure, as demonstrated by BARRO and SALA-I-MARTÍN (1992) with a growth model.

${ }^{4}$ MORRISON and SCHWARTZ (1996) make a similar simplification, including energy products but excluding other intermediate inputs. Their reasons for this are twofold: firstly, the difficulty involved in working out quantity and price indices for the United States. The authors consider that, although some of the benefits of infrastructure may lie in savings in intermediate inputs, the data at their disposal would be inadequate to reflect the fact. In the second place, they point out that their attempts to include other intermediate inputs gave rise to estimations which were much more sensitive when it came to specifying and fixing the parameters for the model.

${ }^{5}$ We have tried other public capital aggregations, such as the so-called "economic infrastructure" (EI) which is taken to include transport, hydraulic and urban infrastruture. The estimations with EI yield similar results to the ones with PC. We have decided not to use more than one public capital variable in the same regression, because of the colinearity problem.

${ }^{6}$ This is the concept used by SEITZ (1993 and 1994) and SEITZ and LICHT (1995). Other authors include in the formula the investment tax credit and the present value of capital consumption allowances multiplied by the tax rate. 
${ }^{7}$ Generally long-term public debt rates are used, but we do not have at our disposal an uninterrupted series of these. Also, electricity share rates are better at capturing the private sector risk premium.

${ }^{8}$ The results of NADIRI and MAMUNEAS (1994) hardly vary when the stock of capital is not adjusted. SEITZ (1994) observes that his results improve when the public capital is adjusted, although the differences do not seem very great. MORRISON and SCHWARTZ (1996) make no adjustment, although they incorporate capital with one lag. ${ }^{9}$ We have tried other specifications, including random effects, but the log-likelihood ratios and the Hausman test indicate that the fixed effects model is preferable.

${ }^{10}$ SEITZ and LICHT, (1995), for example estimate an average elasticity of 0,129 for the Länder using a definition of infrastructure similar to the broadest of those used in this paper.

${ }^{11}$ In some regions the problem of underemployment in the agricultural sector is a familiar one. In fact, costs for some regions and for some years exceed the value added. Another problem is that the depreciation rates of private capital in agriculture are much lower than in other sectors, and show a much greater regional variation, all of which influences private capital stock and capital costs.

12 This variable has only been created for the fifteen Autonomous Communities of mainland Spain. For the Balearic and Canary Islands ED represents their own stock of transport infrastructures. 


\section{References}

ARROW, M.J. and KURZ,M. (1970): Public Investment, the Rate of Return, and Optimal Fiscal Policy, Resources For the Future, Baltimore. The John Hopkins Press.

ARCARONS, J., PARELlADA, M., and SOY, A. (1992): El arco mediterraneo del desarrollo económico español. Delimitación y relaciones interiores, Ejes territoriales de desarrollo: España en la Europa de los noventa.. Colegio de Economistas de Madrid, Colección Economistas libros.

ASCHAUER, D (1989): Is Public Expenditure Productive?, Journal of Monetary Economics 23, pp. 177-200.

BARRO, R. and SALA-I-MARTÍN, X. (1992): Public Finanace in Models of Economic Growth, Review of Economic Studies 59, pp. 645-661.

BERNDT, E.R. (1991): The practice of econometrics, classic and contemporary. AdisonWesley, New York.

BERNDT, E.R. and HANSSON, B. (1992): Measuring the contribution of public infrastructure capital in Sweden, The Scandinavian Journal of Economics 94, pp 151-168.

BIEHL, D. et al (1986): The contribution of infrastructure to regional development., Final Report.. European Community, Luxemburg.

CHAMBERS, R. (1988): Applied Production Analysis. Cambridge University Press, Cambridge.

DE LA FUENTE, A. (1996): Infraestrcuturas y productividad. Un panorama de la evidencia empírica, Información Comercial Española 757, pp. 25-40.

DENO, K. (1988): The effects of public capital on U.S. manufacturing activity: 1970 to 1987. Southern Economic Journal 53, pp. 400-411.

DIEWERT, W.E. (1986): The Measurement of the Economic Benefits of Infrastructure Services, Lecture Notes in Economics and Mathematical Systems 278, SpringVerlag, Berlin Heidelberg. 
EVANS, P. and KARRAS, G. (1994): Are goverment activities productive? Evidence from a panel of U.S. States, The Review of Economics and Statistics 1, pp. 1-11.

EVANS, P. and KARRAS, G. (1994): Is goberment capital productive? Evidence form a panel of seven countries. Journal of Macroeconomics 16 (2), pp. 271-279.

GRAMLICH, E.M. (1994): Infrastructure investment: a review essay, Journal of Economic Literature, vol. XXXII (3), pp. 1176-1196.

GROSSMAN, H.J. and LUCAS, R.F. (1974): The Macroeconomics Effects of Productive Public Expenditures, The Manchester School of Economics and Social Studies 42, pp 162-170.

HOLTZ-EAKIN, D. (1994): Public sector capital and the productive puzzle, Review of Economics and Statistics 76(1), pp. 12-21.

HOLTZ-EAKIN, D. and SCHWARTZ, A.E. (1995): Spatial Productivity Spillovers from Public Infrastructure: Evidence from State Highways, International Tax and Public Finance 2, pp. 459-468.

JORGENSON, D. (1963): Capital theory and investment behaviour, American Economic review 53, pp.247-259.

LYNDE, C. and RICHMOND, J. (1993): Public capital and long-run costs in U.K. manufacturing, The Economic Journal 103, pp. 881-893.

MAS, M., MAUDOS, J. PEREZ, F. and URIEL, E. (1994): Capital público y productividad en las regiones españolas, Moneda y Crédito 198, pp 163-193.

MERA, K. (1973): Regional productions functions and Social Overhead Capital: An Analysis of the Japanese Case, Regional and Urban Economics 3, pp. 157-186.

MORRISON C.J. and SCHWARTZ, A.E. (1996): State Infrastructure and Productive Performance, The American Economic Review vol. 86, 5, pp. 1095-1111.

MUNNEL, A. (1990a): Why has productivity declined? Productivity and Private Investment, New England Economic Review, Federal Reserve Bank of Boston, january-february, pp. 3-22. 
MUNNEL, A. (1990b): How does public infrastructure affect regional economic performance?, New England Economic Review, Federal Reserve Bank of Boston, september-october, pp. 11-32.

NADIRI, M.I. and MAMUNEAS, T.P. (1994): The effects of public infrastructure and R\&D capital on the cost strcuture and perfromance of U.S. manufacturing industries, The Review of Economics and Statistics 1, pp 22-37.

RATNER, J. (1983): Goverment capital and the production function for U.S private output, Economic Letters 13, pp. 213-217.

SEITZ, H. (1993): A dual economic analysis of the benefits of the public road network, The Annals of Regional Science. 27, pp. 223-239.

SEITZ, H. (1994): Public capital and the demand for private inputs, Journal of Public Economics 54, pp. 287-307.

SEITZ, H. and LICHT, G. (1995): The Impact of Public Infrastructure Capital on Regional Manufacturing Production Cost, Regional Studies 29.3, pp.231-240. 